\title{
Contribution of records management to audit opinions and accountability in government
}

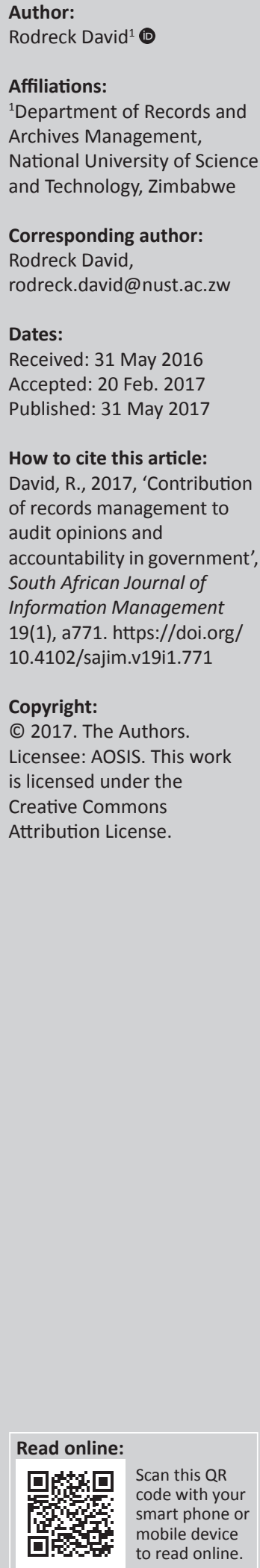

Background: Auditing can support national democratic processes, national development and government good will. Supreme Audit Institutions (SAI), such as offices of Auditor General, publish consolidated reports on audit outcomes for local authorities, government departments, parastatals and related public entities. These reports identify broad areas analysed during audit exercises that often include financial management, governance, asset management, risk management, revenue collection and debt recovery. They highlight trends that were detected during audit exercises at the end of a financial year. The reports further show how records and records management affect audit exercises as well as financial management within the audited institutions.

Objectives: The intention of the research was to ascertain the contribution of records management to audit opinions and accountability in financial management in Zimbabwean government entities.

Method: A document analysis of Comptroller and Auditor General of Zimbabwe (CAGZ)'s reports was used to identify the types of decisions and recommendations (audit opinions) issued, in juxtaposition to the records management issues raised.

Results and Conclusion: This study shows that there is a strong correlation between records management concerns and audit opinions raised by the CAGZ's narrative audit reports. Inadequate records management within government entities was associated with adverse and qualified opinions and, in some cases, unqualified opinions that had emphases of matter. There was a causal loop in which lack of documentary evidence of financial activities was the source cause of poor accounting and poor audit reports. Errors resulting from incomplete or inaccurate records meant that government entities were not showing a true picture of their financial status and their financial statements could be materially misstated. As an important monitoring and control system, records management should be integrated into the accounting and auditing processes of government entities.

\section{Introduction}

Audit reports resulting from accounting information from public institutions are an indispensable information resource that can improve or advance government efforts to public democracy and development. Creditors and investors use audit reports from Supreme Audit Institutions (SAI) to make decisions on financial investments. As explained by Chen, Srinidhi and Su (2014:223), auditing derives its value by increasing the credibility of financial statements, which subsequently increases investors' reliance on them. Legislative and anti-corruption entities use financial auditing information to keep track of the actions of public administrators on behalf of concerned citizens. In the government, auditing is a check mechanism on behalf of the citizen, to ensure that public finances, resources and trust are managed in entities created to foster good governance, such as local authorities, parastatals, government departments, ministries and related government bodies.

Also, the provision of governmental accounting information to citizens supports the 'right to know' and 'to openly receive declared facts' that may lead to open deliberations by the constituents on their chosen councils and legislatures, all of which supports socio-political democracy (Stalebrink \& Sacco 2007:494). Therefore, auditing of public institutions has a social role, considering that the opinions issued by the auditors help citizens to comprehend the implications of the information contained in the financial statements. It is on this basis that citizens make decisions that can alter the democratic processes, social structures and the quality of persons elected or entrusted to run public offices (Lungeanu 2015:358-359). Consequently, governmental auditing activities through an SAI and the resultant reports or information allow citizens to 
participate in the democratic processes such as public debates, enlightened political opinions, lobbying and voting.

Robust auditing structures can also improve a country's economic development (Abdolmohammadi \& Tucker 2002). They foster accountability, transparency and good governance in financial management within public and government institutions. The value of auditing is in its ability to provide an independent guarantee of the trustworthiness of accounting information, and this fosters good management of public resources (DeFond \& Zhang 2014:275). Accountability implies that organisations and individuals can 'explain their actions to others in a transparent and justifiable manner' (Ngulube 2004:24; Ngoepe \& Ngulube 2013:45).

Through the mandate enshrined in the Constitution of Zimbabwe Act [No. 20], the Public Finance Management Act (PFMA) [Chapter 22: 19] and the Audit and Exchequer Act (AEA) [Chapter 22: 03], the Comptroller and Auditor General of Zimbabwe (CAGZ) has a vital role of facilitating good financial management and public accountability. This is pivotal in democratic governance. These Acts require accounting officers, auditors and related financial management officers to manage the resources allocated to their institutions and to be accountable for these resources. CAGZ facilitates accountability and promotes financial management in the use of public resources through carrying out and producing reports on audit outcomes in public institutions. These reports provide a narrative account of the findings, recommendation and related audit opinions of the outcomes of audit activities by the SAI in government bodies across the country. The narrative audit reports identify areas of concern and present them in major themes, stressing on specific tendencies that were noticed during audit exercise(s), as well as the overall opinion of the CAGZ. They narrate the audit findings, the recommendations made by the CAGZ as well as feedback or responses given by the management to key issues raised.

For SAIs such as CAGZ to produce effective reports, they depend on source evidence from the institutions being audited. Evidence-based reporting and the management of such evidence to be used to prove the responsibility of actions and accountability of decisions form the thrust of transparent financial management. Such evidence is found in official records that document the business actions of public service workers, particularly those involved in financial management. As such, effective management of records forms the base of financial management systems and subsequently supports audit exercises with evidence from records. Therefore, where accountability is concerned, 'lack of records management is unthinkable' (Ngoepe \& Ngulube 2013:46). Records management, being the base of auditing, it is an obvious public interest too.

Mismanagement of financial records has long been known to support fraud and corruption activities (Palmer 2000;
Rezaee 2005; Thurston 1997; Vanasco 1998). This often emanates from poor record-keeping systems and is worse and prevalent in the public sector in developing countries where paper records are used widely (Nengomasha 2013:2-3; Ngulube \& Tafor 2006:60-70). It includes failure to create expenditure files, misfiled or non-existent account receivable and payable records, all of which often result in material misstatement of financial statements and enable fraudulent financial reporting. Maintenance of proper and adequate accounting records of financial transactions in government entities is a legal obligation through Section 35 (6) (a) of the PFMA and Section 19 of the AEA in Zimbabwe. It is not surprising that record-keeping receives a considerable amount of deserved attention by SAIs (Everett, Neu \& Rahaman 2007; Ngoepe \& Ngulube 2013) and that emphasis on proper record-keeping is placed in auditing standards such that some SAIs emphasise that 'a clear trail of supporting documentation that is easily available and provided timely is listed as the first of six good-practice indicators of positive audit results' (Bhana 2008:6).

This study replicates a similar one done in South Africa by Ngoepe and Ngulube (2013). In this study, a total of six narrative audit outcomes reports from the CAGZ, of national and local authorities, government departments, parastatals and related public entities for the period between 2011 and 2014 were examined using document analysis to identify the trends in audit opinions with regard to records management vis-à-vis audit opinions. The expectation was that this study would motivate further research in the area of embedding records management within financial management and auditing processes in government bodies. Audited public institutions are expected to benefit by appreciating the extent of contribution and value of records management work which is often treated with low priority (Kemoni 2007:156, 231; Smith 2007:215). The management stratum in government entities is therefore expected to use recommendations from this work to put strategies that endeavour towards unqualified audit opinions.

\section{Research problem, hypothesis and intents}

The CAGZ's opinions in several narrative reports showed her concerns on audit outcomes in several areas of financial management in the government entities. In these areas, the CAGZ had specifically identified record-keeping amongst the key areas that hindered government entities from attaining and upholding unqualified audits. There appeared to be a correlation between record-keeping and audit opinions. The extent of contribution of records management concerns to audit opinions by the CAGZ had not yet been reported in any financial, auditing or records management studies in Zimbabwe. Therefore, this study sought to analyse 
the narrative audit outcomes reports of the CAGZ from 2011 to 2014 to determine the extent of contribution of records management concerns to CAGZ's audit opinions and government accountability in Zimbabwe.

Considering this, the study intended to:

- establish the reporting trends in the CAGZ's narrative audit outcomes reports in relation to records management concerns from 2011 to 2014

- analyse and interpret word use metrics surrounding records management in the narrative reports

- analyse and interpret the concordance and contextual usage of record-keeping terms in audit findings

- establish a causal loop relationship between records management concerns and audit outcomes.

\section{Research methods}

This study was confined to the analysis of CAGZ's narrative audit outcomes reports for government entities that include local authorities, parastatals, state enterprises and related public entities. A total of six reports were analysed which were for the period between 2011 and 2014. A document analysis was conducted to gather relevant data about the contribution of records management concerns to audit opinions reflected in the CAGZ's reports. Document analysis is a technique that uses both quantitative and qualitative methods to understand the trend of desired issues within written or printed documents (document analysis further includes image and graphics analysis). Quantitative methods are based on statistical analysis, whereas qualitative methods hinge on semantic inferences using text retrieval and presentation techniques.

Document analysis was used because of its unobtrusive nature as it is dependent on objects (i.e. reports, books, articles, web pages, etc.) rather than humans (similar to Ngoepe \& Ngulube 2013:46). This eliminated the Hawthorne or observer effect, which is a human-based reaction that would lead to bias, as humans can modify their behaviour because they are being studied (Breznau 2016:302). Also, because document analysis data sources exist before the study, they have a degree of objectivity based on the fact that the data sources were produced without the influence of their creators (Singleton \& Straits 2010:403). Also, reports are often publicly available. In this case study, the CAGZ's narrative audit reports on audit outcomes available in the website (http://www.auditgen.gov.zw/index.php/reports) were used. As such, document analysis is one of the more forthright ways to trigger broader or detailed research.

The electronic reports that were in portable document format were analysed using software tools from Provalis Research (QDA Miner and WordStat) to establish the CGAZ's reporting trends on records management concerns, to analyse and interpret word use metrics surrounding records management in the narrative reports, to analyse and interpret the concordance and contextual usage of record-keeping terms in audit findings and to establish a causal loop relationship between records management concerns and audit outcomes.

\section{Presentation of research results}

The research objectives were used as a guide in presenting the results that came out of document analysis. These are presented here, with a follow up discussion of the results and their implications after which relevant conclusions and recommendations are made.

\section{Analysis of audit opinions vis-à-vis records management concerns}

Table 1 presents the CAGZ Audit Opinions and Records Management Concerns in State Enterprises and Parastatals from the 2014 Narrative Report (see Table 2 report no. 6). As shown, the correlation between records management concerns and audit outcomes was close, such that in all cases where the concerns were emphasised, there was either unqualified opinion with an emphasis of matter, a qualified opinion or an adverse opinion. Generally, the results show that there are poor regimes of records management in most government entities.

\section{Analysis of records management concerns through text mining}

Text mining was used to detect and bring out concerns raised about records management in the audit reports (Box 1). The keyword-in-context (KWIC) analysis method was used to extract specific concerns raised using keywords such as record-keeping, record-keeping, record*, poor, keep*, maintain*, deleted, inadequate, weak*, proper, failure, financial statement, receipt, accurate*, complete*, register, book* and document*. Frequency of word use was also used to show the level of concern around records management. Table 3 shows an extract of the top frequently used words in the six reports, highlighting the use of record-related terms and emphasising frequency of reference.

The strength of the relationship between words, keywords and content categories (in this case, the reports) was analysed using statistical predictors. This analysis established the occurrence of selected keywords within six cases (the reports) (Table 4). As shown in Table 4, there was a high probability of the occurrence of the words records and keeping [probability $(P)=1$ in both cases] in all the reports. Simple word use frequency analysis showed that terms relating to records management where high up the graph with the word 'record' itself being the fourth frequently used word in the reports (Figure 1). A heatmap plot was used to graphically present a crosstab analysis where cell frequencies were represented by different colour-brightness or tones. The tool enabled an exploratory analysis of the functional relationships and cluster similarities between specific keywords. For instance, in the heat map in Figure 2, there was a strong emphasis on record-keeping in all the reports especially in report no. 5 (Table 2). Also, a keyword Dendrogram (Figure 3) was used to show the similarity relationship between words emphasised in the reports. Using a similarity index of 
TABLE 1: The Comptroller and Auditor General of Zimbabwe audit opinions and records management concerns in state enterprises and parastatals from the 2014 narrative report (see Table 2, report no. 6)

\begin{tabular}{|c|c|c|}
\hline Government Entities & CAGZ's audit opinions & Records management concerns \\
\hline \multicolumn{3}{|l|}{ Authorities and agencies } \\
\hline Agricultural Marketing Authority (AMA) & Unqualified Opinion & None Noted \\
\hline Broadcasting Authority of Zimbabwe (BAZ) & Unqualified Opinion & None Noted \\
\hline Civil Aviation Authority of Zimbabwe (CAAZ), 2013 & Unqualified Opinion & None Noted \\
\hline Environmental Management Agency, 2013 & Unqualified Opinion & None Noted \\
\hline Health Professions Authority (HPA) & Unqualified Opinion & None Noted \\
\hline Medicines Control Authority of Zimbabwe & Unqualified Opinion & None Noted \\
\hline National Biotechnology Authority, 2010-2012 & Qualified & Emphasised \\
\hline National Social Security Authority (NSSA), 2013 & Qualified & Emphasised \\
\hline Postal and Telecommunications Regulatory Authority of Zimbabwe (POTRAZ) & Qualified & Emphasised \\
\hline Radiation Protection Authority of Zimbabwe, 2013 & Unqualified Opinion & Noted \\
\hline Zimbabwe Energy Regulatory Authority (ZERA) & Unqualified Opinion & Noted \\
\hline Zimbabwe Investment Authority (ZIA) & Unqualified Opinion & Noted \\
\hline Zimbabwe National Road Administration (ZINARA), 2012-2013 & Qualified & Emphasised \\
\hline Zimbabwe Revenue Authority (ZIMRA) \& Its Subsidiary, 2013 & Unqualified Opinion & Noted \\
\hline \multicolumn{3}{|l|}{ Boards } \\
\hline Grain Marketing Board (GMB), 2013 & Qualified & Emphasised \\
\hline Health Service Board (HSB), 2013 & Unqualified Opinion & Noted \\
\hline National Indigenisation and Economic Empowerment Board & Unqualified Opinion & Noted \\
\hline Tobacco Industry and Marketing Bard (TIMB) & Unqualified Opinion & Noted \\
\hline Tobacco Research Board & Unqualified Opinion & Noted \\
\hline \multicolumn{3}{|l|}{ Commissions } \\
\hline Anti-Corruption Commission of Zimbabwe, 2010 & Adverse Opinion $\dagger$ & Emphasised \\
\hline Competition and Tariff Commission & Unqualified Opinion & Noted \\
\hline Forestry Commission & Unqualified with an Emphasis of matter & Emphasised \\
\hline National Income and Pricing Commission (NIPC) & Unqualified Opinion & Noted \\
\hline Securities and Exchange Commission of Zimbabwe (SECZ) & Unqualified Opinion & Noted \\
\hline Investor Protection Fund (for SECZ) & Unqualified with an Emphasis of matter & Emphasised \\
\hline \multicolumn{3}{|l|}{ Companies corporations } \\
\hline Allied Timbers (Pvt) Ltd & Unqualified with an Emphasis of Matter & Emphasised \\
\hline CMED (Pvt) Ltd & Unqualified Opinion & Noted \\
\hline Cold Storage Company and its Subsidiary Wetblue Industries (Pvt) Ltd & Unqualified with an Emphasis of Matter & Emphasised \\
\hline Courier Connect & Unqualified with an Emphasis of Matter & Emphasised \\
\hline Deposit Protection Corporation & Unqualified Opinion & Noted \\
\hline Life Long Engineering & Unqualified Opinion & Noted \\
\hline Marange Resources (Pvt) Ltd, 2013 & Unqualified with an Emphasis of Matter & Emphasised \\
\hline Minerals Marketing Corporation of Zimbabwe (MMCZ) & Unqualified Opinion & Emphasised \\
\hline Mellofield (under MMCZ) & Qualified Opinion on Legal and Regulatory Matters & Emphasised \\
\hline National Oil Infrastructure Company of Zimbabwe (NOIC) & Unqualified Opinion & Noted \\
\hline National Pharmaceuticals (NATPHARM) & Unqualified Opinion & Noted \\
\hline National Railways of Zimbabwe (NRZ), 2013 & Unqualified with an Emphasis of Matter & Emphasised \\
\hline Net *One Pvt Ltd & Unqualified Opinion & Noted \\
\hline New Ziana & Unqualified Opinion & Noted \\
\hline Petrotrade (Pvt) Ltd, 2014 & Unqualified Opinion & Noted \\
\hline Powertel Communications (Pvt) Ltd, 2013 & Unqualified with an Emphasis of Matter & Emphasised \\
\hline Printflow (Pvt) Ltd & Unqualified Opinion & Noted \\
\hline Saint Lucia Park Training and Conference Centre (Pvt) Ltd & Unqualified Opinion & Noted \\
\hline TelOne (Pvt) Ltd & Unqualified with an Emphasis of Matter & Emphasised \\
\hline ZESA Enterprises (ZENT) Pvt Ltd, 2013 & Unqualified Opinion & Noted \\
\hline ZESA Holdings & Unqualified Opinion & Noted \\
\hline Zimbabwe Academic and Research Network (ZARNet) Ltd, 2011-2013 & Unqualified Opinion & Emphasised \\
\hline Zimbabwe Mining Development Corporation (ZMDC) and its Subsidiaries, 2013 & Adverse opinion with an emphasis of matter & Emphasised \\
\hline Zimbabwe Posts (Pvt) Ltd (ZIMPOST) & Qualified Opinion with an emphasis of matter & Emphasised \\
\hline Zimbabwe Power Company (ZPC) & Unqualified Opinion & Noted \\
\hline ZimTrade & Qualified Opinion & Emphasised \\
\hline Zimbabwe Transmission and Distribution Company (ZETDC) & Unqualified Opinion & Noted \\
\hline
\end{tabular}


TABLE 1 (Continued): The Comptroller and Auditor General of Zimbabwe audit opinions and records management concerns in state enterprises and parastatals from the 2014 narrative report (see Table 2, report no. 6).

\begin{tabular}{|c|c|c|}
\hline Government Entities & CAGZ's audit opinions & Records management concerns \\
\hline \multicolumn{3}{|l|}{ Councils } \\
\hline Allied and Health Practitioners Council & Unqualified Opinion & Noted \\
\hline Environmental Health and Practitioners of Zimbabwe (EHPC) & Unqualified Opinion & Noted \\
\hline Medical and Dental Practitioners Council & Unqualified Opinion & Noted \\
\hline Medical Rehabilitation Practitioners Council & Unqualified Opinion & Noted \\
\hline National Aids Council (NAC) & Unqualified Opinion & Noted \\
\hline National Arts Council of Zimbabwe (NACZ), 2013 & Unqualified Opinion & Noted \\
\hline Nurses Council of Zimbabwe & Unqualified Opinion & Noted \\
\hline Pharmacist Council of Zimbabwe & Unqualified Opinion & Noted \\
\hline Research Council of Zimbabwe (RCZ) & Unqualified Opinion & Noted \\
\hline Traffic Safety Council of Zimbabwe & Unqualified Opinion & Noted \\
\hline Zimbabwe Council for Higher Education (ZIMCHE) & Unqualified Opinion & Noted \\
\hline Zimbabwe National Family Planning Council (ZNFPC), 2013 & Unqualified Opinion & Noted \\
\hline Zimbabwe School Examinations Council (ZIMSEC) & Unqualified Opinion & Noted \\
\hline Agribank & Unqualified with an Emphasis of Matter & Emphasised \\
\hline Infrastructure Development Bank of Zimbabwe (IDBZ) & Unqualified with an Emphasis of Matter & Emphasised \\
\hline People's Own Savings Bank (POSB) & Unqualified Opinion & Noted \\
\hline Small Enterprises Development Corporation (SEDCO) & Qualified Opinion & Emphasised \\
\hline Ingutsheni Central Hospital & Unqualified Opinion & Noted \\
\hline Parirenyatwa Group of Hospitals & Unqualified Opinion & Noted \\
\hline United Bulawayo Hospitals & Adverse Opinion & Emphasised \\
\hline \multicolumn{3}{|l|}{ Universities and tertiary institutions } \\
\hline Bindura University of Science and Education & Unqualified Opinion & Noted \\
\hline Bulawayo School of Hospitality and Tourism & Unqualified Opinion & Noted \\
\hline Chinhoyi University of Technology \& the Hotel & Unqualified Opinion & Noted \\
\hline Great Zimbabwe University & Unqualified Opinion & Noted \\
\hline Harare Institute of Technology & Unqualified Opinion & Noted \\
\hline Judicial College of Zimbabwe & Unqualified Opinion & Noted \\
\hline National University of Science and Technology & Unqualified Opinion & Noted \\
\hline University of Zimbabwe & Unqualified Opinion & Noted \\
\hline Zimbabwe Open University (ZOU), 2013 & Unqualified Opinion & Noted \\
\hline Zimbabwe School of Mines (ZSM) & Unqualified Opinion & Noted \\
\hline \multicolumn{3}{|l|}{ Other } \\
\hline National Galleries of Zimbabwe & Unqualified Opinion & None Noted \\
\hline National Museums and Monuments of Zimbabwe (NMMZ) & Unqualified with an Emphasis of Matter & Emphasised \\
\hline Scientific and Industrial Research Development Centre (SIRDC) & Unqualified Opinion & Noted \\
\hline
\end{tabular}

$\dagger$, It was interesting to note that the Anti-Corruption Commission had an adverse opinion as well as emphasised records management concerns considering its role as an institution set to foster accountability and government transparency.

TABLE 2: The Comptroller and Auditor General of Zimbabwe (CAGZ) reports analysed in this study.

\section{Report CAGZ reports analysed in this study}

$1 \quad$ Narrative Report on Finance Accounts Statements in the Ministry of Finance and Economic Development 2011:

- Statement of Public Financial Assets 2011

- Statement of Receipts and Disbursements 2011

- Statement of Contingent Liabilities 2011

2 Narrative Report on Finance Accounts Statements in the Ministry of Finance and Economic Development 2012:

- Summary of Transactions on the Exchequer Account 2012

- Summary of Transactions on the Consolidated Revenue Fund 2012

- Statement of Public Financial Assets 2012

- Statement of Public Debt 2012

- Statement of Contingent Liabilities 2012

3 Report of the Comptroller and Auditor General for the Financial Year Ended December 31, 2011 - Narrative Report on Appropriation Account and Miscellaneous Funds and Donor Funded Projects Volume I of III

4 Report of the Auditor General for the Financial Year Ended December 31, 2012 - Local Authorities Volume III of III

5 Report of the Auditor General for the Financial Year Ended December 31 2014 - Narrative Report on Appropriation Accounts and Miscellaneous Funds

6 Report of the Auditor General for the Financial Year Ended December 31, 2014 - Narrative Report on State Enterprises and Parastatals
3 and with 10 clusters, the results in Figure 3 show that accounts, accounting, proper, system, maintenance and records were correlated and commonly used together in the reports. Clearly, the above textual analysis highlights a high level of concern of records management issues raised in the reports.

\section{Analysis of concordance and contextual usage of record-keeping terms in audit findings}

All of the six reports (Table 2) analysed in this study were subjected to a concordance and contextual usage test of the word record*. The results presented in Figures 4-9 were interesting. They pointed out all the instances in which the term appeared and the contexts in which it was used. Interestingly, the visual presentations show many cases in which the term record* was linked to concerns such as poor record-keeping, lack of sound record-keeping systems, inadequate 
BOX 1: Key records management concerns mined using the KWIC method.

Key records management concerns mined using the KWIC method (record-keeping, record-keeping, record*, poor, keep*, maintain*, deleted, inadequate, weak*, proper, failure, financial statement, receipt, accurate*, complete*, register, book*, document*):

- The Fund should maintain a record of its payments to schools in order to monitor and use the information for planning and budgeting purposes.

- An annual inspection of assets should be conducted and the Master Asset Register updated in order to come up with a correct record of assets.

- Inadequate record-keeping. Treasury did not keep proper records of account for Public Financial Assets as the records were fragmented in contravention of Section 35 (6) (a) of

the Public Finance Management Act (Chapter 22:19).

- An annual inspection of assets should be conducted and the Master Asset Register should be updated in order to come up with a correct record of the Ministry`s assets.

- Poor record-keeping of property files. Property files for stand number 309, 434, 481 and 666 are yet to be updated with lease agreements.

- Adequate books of accounts should be maintained to record and disclose all the financial information.

- A record of all fuel coupons received and issued should be kept and regular checks by responsible officers should be carried out as a control measure.

- A record of security items should always be maintained in compliance with the provisions of Treasury Instruction 2101.

- A site visit of the Public Sector Investment Programmes (PSIP) on construction of school buildings, revealed weaknesses in record-keeping of building materials.

- As a result, there was no record for the following receipt books 056201-056300, 056401-056500, 725101-725200 and invoice book number 139501-139550 that were in use

at the centre for the year under review.

- Council should maintain a proper receipt book record which shows all receipt books issued and returned.

- Council maintains the following record books to cater for under and over banking.

- Council should generate duplicate record of building inspection fees, one should be given to client and the other one should be filed.

- Due to poor record-keeping and weak supervisory controls, the Balance Sheet had a credit suspense account of \$3536 135 (2011: \$2 713 457).

- Failure to record and prepare financial statements may result in loss of transactions information for the years the fund has been in operation.

- Failure to record assets in the Master Assets Register may result in late detection of thefts and misuse of assets.

- Furthermore, receipt book number 725101-725200 was not recorded on the stores register neither is there record of who is currently using it.

- Good accounting practice requires that an entity should use a secure and robust accounting package to record and maintain its financial information.

- I observed that although financial statements were prepared from schedules maintained on Microsoft Excel spreadsheets no reliance could be placed on the accounts due to lack of a permanent record.

- In the absence of a register for Contingent Liabilities and sound record-keeping system I could not place reliance on the opening balance disclosed.

- In the absence of a sound record-keeping system audit could not therefore, establish the completeness and accuracy of the figures disclosed on the return submitted for audit.

- Inadequate record-keeping and non-disclosure of investments.

- It becomes difficult to establish the completeness and accuracy of the figures disclosed on the return submitted for audit if a sound record-keeping system is not in place.

- Management response - A follow up with Zimbabwe Parks and Wildlife Management Authority will be done to have a record of their movement and disposal.

- No register was maintained to record all private colleges registered with the Ministry of Higher and Tertiary Education.

- Recommendation - Council should generate duplicate record of building inspection fees, one should be given to client and the other one should be filed.

- Recommendation - The Fund should fully utilise the accounting system to record and process all financial transactions.

- Recommendation. The Local Board should enter into loan agreements when advancing loans to its staff and maintain a record of such agreements. Recommendation - The

Recommendation. The Local Board should enter into loan agreements when advancing loans to its staff and maintain a recor

- Recal Board should enter into loan agreements when advancing loans to its staff and maintain a record of such
Recommendation - The Ministry should record all its advance payments in a register to facilitate follow ups.

- Risk/Implication - In the absence of proper record-keeping, some accounting transactions might not be recorded and processed thereby affecting the accuracy and completeness of financial information.

- Risk/Implication - Lack of proper record-keeping system may create opportunity for fraud.

- Risk/Implication - Misappropriation of assets may occur and remain undetected as no complete record of assets exists.

- Risk/Implication - Misappropriation of assets may occur and remain undetected as no complete record of assets exists.

- Section 10 (1) of War Veterans Act [Chapter 11:15] states that proper books of accounts and records should be used to record all financial transactions of the Fund.

- Supporting documents must be attached to the bills of entry retained for record-keeping.

- Supporting documents must be attached to the motor vehicle change of ownership form and retained for record-keeping.

- The Council does not have a central record of all computers used for billing and receipting.

- The Ministry should put in place an effective monitoring mechanism such as maintaining a database of all the registered businesses, periodic inspection of the premises and a record of land allocated to council for residential purposes should be put in place.

- The Council should ensure that adequate controls and suitable accounting package are in place to allow for good record-keeping.

- The Fund did not maintain a manual cashbook and ledgers on which to record financial transactions.

- The Ministry did not maintain an up-to-date consolidated Master Asset Register to record all assets in terms of Treasury Instruction 2002.

- The anomaly could have been as a result of poor record-keeping or theft of the un-acquitted cash.

- The extent of guarantees and commitments disclosed may be misstated, in the absence of a sound record-keeping system.

- The proceeds of the sale of these stands have no record on council funds.

- The register could not give accurate information and dates as to movement of records as some sections like when the record was sent to High Court was left blank despite the records having been returned back from High Court.

- There was no improvement in record-keeping.

- There was no proper accounting, regular stock taking, complete record-keeping, reconciliations or even spot audits being done for the City's security items.

- There is a risk that without any record, the assets may be lost or misappropriated.

- There is no record of how these receipt books were transferred to Harare Institute of Technology.

- There should be a standard procedure for recording stocks which is uniform so that the year-end returns reflect a true record of the stocks on hand.

- Therefore, in the absence of a sound record-keeping system I could not establish the completeness and accuracy of the figures disclosed on the return submitted for audit.

- Therefore, there was no record of the computers that had the receipting module installed on them or were authorized to have this software.

- This was caused by inadequate supervision and improper record-keeping.

- This module however was not being utilised to capture and record such information of land sold and yet to be sold.

- This was caused by poor record-keeping and lack of supervision.

- This was caused by inadequate record-keeping.

- Risk/Implication Without registers, the Fund will not have a full record of Housing units and stands and details of beneficiaries of the housing scheme. This was caused by

inadequate record-keeping.

- This was caused by poor record-keeping. Treasury had an incomplete record of receipt books issued and this was compounded by the fact that the following four receipt books were missing: 347701- $348000349201-349500007601-007700007701-007800$.

Treasury had an incomplete record of receipt books issued and this was compounded by the fact that the following four receipt books were missing: $347701-348000349201$ $349500007601-007700007701-007800$. Some receipts from the sub-offices had no master receipts to show that they were receipted at the main offices.

- When an employee's name is deleted in the system, all the record of payments made to such an employee are lost.

- Register in place to record fuel received from suppliers and issued out to users for the period January to May 2011.

- The situation did not improve owing to inadequate records and as a result the Ministry has been qualified on the same issue during the current year.

- Failure to carry out an annual asset assessment may result in maintaining or keeping redundant and unserviceable assets on record.

- No record or proof of disposal of the exhibits was availed for audit.

- Parliament of Zimbabwe did not open books of accounts to record the indebtedness of the Members of Parliament to government.

- Recommendations - An up-to-date record of debtors should be maintained so that schools do not loose potential revenue.

record-keeping or failure to keep accurate or correct records, all of which was common in all the six reports (Figures 4-9).

\section{Discussion of the results}

Document analysis of the narrative reports of the CAGZ strongly confirms the hypothesis of a strong correlation between record-keeping and audit opinions (Table 1). This replicates results from a similar study done in South Africa by Ngoepe and Ngulube (2013), which showed a strong link between record-keeping and audit outcomes and accountability of public institutions.

The proximity heat map analysis of word use in the six reports shows that record-keeping, evidence and recommendations were highlighted and strongly linked as shown with the lighter heat signature and cluster similarities presented in Figure 2.

In the narrative reports on state enterprises and parastatals for 2013-2014 (see Table 2, report no. 6), adverse, qualified 
TABLE 3: An extract of the top frequently used words in the six reports highlighting the use of record-related terms emphasising frequency of reference.

\begin{tabular}{|c|c|c|c|c|c|c|c|}
\hline Word & Frequency & Shown \% & Processed \% & Total \% & Number cases & Cases $\%$ & $\mathrm{TF} \bullet \mathrm{IDF}$ \\
\hline Financial & 586 & 2.47 & 1.42 & 0.70 & 239 & 38.06 & 245.9 \\
\hline Records & 571 & 2.41 & 1.38 & 0.68 & 432 & 68.79 & 92.8 \\
\hline Ministry & 558 & 2.35 & 1.35 & 0.66 & 229 & 36.46 & 244.5 \\
\hline Management & 517 & 2.18 & 1.25 & 0.62 & 281 & 44.75 & 180.6 \\
\hline Fund & 465 & 1.96 & 1.13 & 0.55 & 152 & 24.20 & 286.5 \\
\hline Assets & 425 & 1.79 & 1.03 & 0.51 & 141 & 22.45 & 275.7 \\
\hline Accounting & 336 & 1.42 & 0.81 & 0.40 & 195 & 31.05 & 170.7 \\
\hline Statements & 331 & 1.39 & 0.80 & 0.39 & 166 & 26.43 & 191.3 \\
\hline Council & 313 & 1.32 & 0.76 & 0.37 & 89 & 14.17 & 265.6 \\
\hline System & 297 & 1.25 & 0.72 & 0.35 & 127 & 20.22 & 206.2 \\
\hline Register & 286 & 1.20 & 0.69 & 0.34 & 136 & 21.66 & 190 \\
\hline Recommendation & 267 & 1.12 & 0.65 & 0.32 & 212 & 33.76 & 125.9 \\
\hline Account & 247 & 1.04 & 0.60 & 0.29 & 127 & 20.22 & 171.5 \\
\hline Implication & 238 & 1.00 & 0.58 & 0.28 & 199 & 31.69 & 118.8 \\
\hline Response & 220 & 0.93 & 0.53 & 0.26 & 187 & 29.78 & 115.7 \\
\hline Finding & 204 & 0.86 & 0.49 & 0.24 & 180 & 28.66 & 110.7 \\
\hline Bank & 204 & 0.86 & 0.49 & 0.24 & 84 & 13.38 & 178.2 \\
\hline Treasury & 200 & 0.84 & 0.48 & 0.24 & 128 & 20.38 & 138.1 \\
\hline Revenue & 200 & 0.84 & 0.48 & 0.24 & 107 & 17.04 & 153.7 \\
\hline Public & 193 & 0.81 & 0.47 & 0.23 & 101 & 16.08 & 153.2 \\
\hline Noted & 187 & 0.79 & 0.45 & 0.22 & 146 & 23.25 & 118.5 \\
\hline Expenditure & 185 & 0.78 & 0.45 & 0.22 & 79 & 12.58 & 166.6 \\
\hline Accounts & 178 & 0.75 & 0.43 & 0.21 & 100 & 15.92 & 142 \\
\hline Ensure & 176 & 0.74 & 0.43 & 0.21 & 144 & 22.93 & 112.6 \\
\hline Cash & 174 & 0.73 & 0.42 & 0.21 & 80 & 12.74 & 155.7 \\
\hline Fuel & 174 & 0.73 & 0.42 & 0.21 & 44 & 7.01 & 200.9 \\
\hline December & 159 & 0.67 & 0.39 & 0.19 & 113 & 17.99 & 118.4 \\
\hline Result & 137 & 0.58 & 0.33 & 0.16 & 121 & 19.27 & 98 \\
\hline Maintain & 137 & 0.58 & 0.33 & 0.16 & 109 & 17.36 & 104.2 \\
\hline Proper & 130 & 0.55 & 0.31 & 0.15 & 91 & 14.49 & 109.1 \\
\hline Maintained & 129 & 0.54 & 0.31 & 0.15 & 107 & 17.04 & 99.1 \\
\hline Finance & 127 & 0.54 & 0.31 & 0.15 & 90 & 14.33 & 107.2 \\
\hline Office & 127 & 0.54 & 0.31 & 0.15 & 86 & 13.69 & 109.7 \\
\hline Time & 126 & 0.53 & 0.31 & 0.15 & 91 & 14.49 & 105.7 \\
\hline Receipts & 126 & 0.53 & 0.31 & 0.15 & 52 & 8.28 & 136.3 \\
\hline Section & 124 & 0.52 & 0.30 & 0.15 & 93 & 14.81 & 102.9 \\
\hline Books & 122 & 0.51 & 0.30 & 0.15 & 70 & 11.15 & 116.2 \\
\hline
\end{tabular}

TF・IDF, term frequency-inverse document frequency

and unqualified opinions which had emphases of matter were heavily linked to records management concerns, featuring absence, inadequate or lack of proper recordkeeping (see Table 1). Supporting this was the text retrieval analysis of key records management concerns mined using terms: record-keeping, record-keeping, record*, poor, keep*, maintain*, deleted, inadequate, weak*, proper, failure, financial statement, receipt, accurate*, complete*, register, book*, document* (see Box 1). The analysis shows a host of records management concerns raised characterised by comments given as follows:

- there were no up-to-date consolidated records of financial transactions

- inaccurate or insufficient information in the records

- poor record-keeping system

- absence of a sound record-keeping system

- records are manual and difficult to obtain

- warehouse records had no regular backup
- the situation did not improve owing to inadequate records, and as a result, the Ministry has been qualified on the same issue during the current year

- did not maintain adequate account records such as cash books, ledgers and related registers

- accountability of donor funds is questionable in the absence of accounting records

- failure to maintain loan guarantee records and a register will make it difficult to monitor and determine the claims and penalties when they fall due and also in the event of a dispute

- these operations are wide, complex and involve large volumes of data. Some manual records could not be retrieved upon audit request such as inventory schedules because they had been misplaced and there was no backup

- there were no records of contracts to support some of the projects that amount to US\$ 2884372.

The above analysis is also evident when looking at the contextual usage and concordance analyses presented in 
TABLE 4: Metrics analysis using statistical predictors for the occurrence of the word 'record' within six cases (the reports).

\begin{tabular}{|c|c|c|c|c|c|c|}
\hline Name & Global Chi $^{2}$ & $p$ & Max $\mathrm{Chi}^{2}$ & $p$ & Biserial & Predict \\
\hline Account & 2.97 & 0.7040 & 0.96 & 0.3265 & 1.6280 & 3 \\
\hline Accounting & 5.49 & 0.3588 & 1.96 & 0.1615 & 3.0743 & $2 \& 6$ \\
\hline Accounts & 6.52 & 0.2590 & 1.55 & 0.2128 & 2.7361 & $2 \& 6$ \\
\hline Act & 4.91 & 0.4266 & 1.61 & 0.2049 & 2.1036 & $3 \& 4$ \\
\hline Agents & 14.32 & 0.0137 & 14.32 & 0.0002 & 10.5376 & 4 \\
\hline Assets & 4.27 & 0.5119 & 3.46 & 0.0628 & 3.2906 & 3 \\
\hline Audit & 4.98 & 0.4181 & 0.67 & 0.4123 & 1.5815 & $2 \& 6$ \\
\hline Bank & 9.60 & 0.0874 & 3.97 & 0.0464 & 4.3729 & $2 \& 6$ \\
\hline Cash & 13.85 & 0.0166 & 5.11 & 0.0238 & 4.9631 & $2 \& 6$ \\
\hline Certificates & 11.25 & 0.0466 & 11.25 & 0.0008 & 5.5656 & 3 \\
\hline City & 9.68 & 0.0848 & 4.37 & 0.0366 & 5.8201 & $2 \& 6$ \\
\hline Clearing & 6.43 & 0.2667 & 3.67 & 0.0553 & 5.3375 & 4 \\
\hline Construction & 8.22 & 0.1445 & 7.79 & 0.0053 & 4.6308 & 3 \\
\hline Contravention & 10.60 & 0.0599 & 7.60 & 0.0058 & 4.3536 & 3 \\
\hline Council & 45.00 & 0.0000 & 20.30 & 0.0000 & 7.9697 & $2 \& 6$ \\
\hline Delays & 4.19 & 0.5230 & 4.19 & 0.0408 & 4.4930 & 3 \\
\hline Department & 3.30 & 0.6536 & 1.96 & 0.1615 & 3.0743 & 2 \\
\hline Disclosed & 4.40 & 0.4927 & 1.82 & 0.1775 & 2.3849 & 5 \\
\hline District & 6.63 & 0.2493 & 3.46 & 0.0628 & 3.2906 & 3 \\
\hline Documents & 10.23 & 0.0688 & 6.39 & 0.0115 & 5.5522 & 4 \\
\hline Ensure & 7.64 & 0.1772 & 1.96 & 0.1615 & 3.0743 & $2 \& 6$ \\
\hline Evidence & 2.76 & 0.7364 & 0.53 & 0.4657 & 2.0314 & 4 \\
\hline Files & 6.63 & 0.2493 & 3.46 & 0.0628 & 3.2906 & 3 \\
\hline Finance & 10.54 & 0.0613 & 6.02 & 0.0142 & 3.7216 & 3 \\
\hline Financial & 2.22 & 0.8180 & 1.61 & 0.2049 & 1.8112 & 3 \\
\hline Finding & 23.20 & 0.0003 & 7.23 & 0.0072 & 4.7560 & $2 \& 6$ \\
\hline Fund & 11.04 & 0.0506 & 8.76 & 0.0031 & 4.2290 & 3 \\
\hline Houses & 6.43 & 0.2667 & 6.43 & 0.0112 & 4.8906 & 3 \\
\hline Housing & 16.58 & 0.0054 & 16.58 & 0.0000 & 6.1780 & 3 \\
\hline Implication & 11.93 & 0.0358 & 2.98 & 0.0842 & 3.3303 & 2 \\
\hline Keeping & 0.00 & 1.0000 & 0.00 & 1.0000 & 0.0000 & $1 \& 2 \& 3 \& 4 \& 5 \& 6$ \\
\hline Maintained & 4.87 & 0.4321 & 1.55 & 0.2128 & 2.7361 & $2 \& 6$ \\
\hline Management & 14.34 & 0.0136 & 7.51 & 0.0061 & 3.6891 & 3 \\
\hline Ministry & 12.41 & 0.0296 & 10.60 & 0.0011 & 4.6518 & 3 \\
\hline Noted & 8.22 & 0.1446 & 3.67 & 0.0553 & 4.2089 & 4 \\
\hline Observation & 3.84 & 0.5729 & 0.53 & 0.4657 & 2.0314 & 4 \\
\hline Observed & 4.86 & 0.4327 & 3.46 & 0.0628 & 2.8230 & 3 \\
\hline Office & 2.92 & 0.7130 & 1.61 & 0.2049 & 2.1036 & $3 \& 4$ \\
\hline Opinion & 6.43 & 0.2667 & 3.67 & 0.0553 & 5.3375 & 4 \\
\hline Payments & 5.66 & 0.3404 & 3.72 & 0.0536 & 3.2024 & 3 \\
\hline Progress & 6.63 & 0.2493 & 3.46 & 0.0628 & 3.2906 & 3 \\
\hline Project & 4.19 & 0.5230 & 4.19 & 0.0408 & 4.4930 & 3 \\
\hline Projects & 8.78 & 0.1181 & 8.78 & 0.0030 & 5.2409 & 3 \\
\hline Proper & 8.39 & 0.1361 & 1.55 & 0.2128 & 2.7361 & $2 \& 6$ \\
\hline Properties & 8.78 & 0.1181 & 8.78 & 0.0030 & 5.2409 & 3 \\
\hline Property & 16.58 & 0.0054 & 16.58 & 0.0000 & 6.1780 & 3 \\
\hline Public & 14.67 & 0.0119 & 10.60 & 0.0011 & 4.6518 & 3 \\
\hline Receipts & 4.58 & 0.4697 & 1.41 & 0.2355 & 3.3034 & $2 \& 6$ \\
\hline Recommendation & 15.51 & 0.0084 & 2.98 & 0.0842 & 3.3303 & $2 \& 6$ \\
\hline Recommendations & 1.52 & 0.9110 & 0.62 & 0.4292 & 1.3982 & 3 \\
\hline Record & 0.00 & 1.0000 & 0.00 & 1.0000 & 0.0000 & $1 \& 2 \& 3 \& 4 \& 5 \& 6$ \\
\hline Records & 3.92 & 0.5604 & 0.40 & 0.5272 & 1.3885 & $2 \& 6$ \\
\hline Register & 2.04 & 0.8438 & 0.36 & 0.5501 & 1.6642 & 4 \\
\hline Response & 18.45 & 0.0024 & 3.43 & 0.0640 & 3.5722 & $2 \& 6$ \\
\hline Risk & 11.93 & 0.0358 & 2.98 & 0.0842 & 3.3303 & 2 \\
\hline Section & 3.47 & 0.6284 & 1.61 & 0.2049 & 2.1036 & 3 \\
\hline Stand & 5.89 & 0.3168 & 2.37 & 0.1236 & 4.2885 & $2 \& 6$ \\
\hline Stands & 6.63 & 0.2493 & 3.46 & 0.0628 & 3.2906 & 3 \\
\hline Statements & 6.29 & 0.2790 & 2.24 & 0.1344 & 2.8874 & $2 \& 6$ \\
\hline Submitted & 1.28 & 0.9370 & 0.38 & 0.5373 & 1.3548 & 1 \\
\hline Suspense & 1.90 & 0.8633 & 0.51 & 0.4745 & 1.5704 & 5 \\
\hline System & 6.44 & 0.2658 & 2.59 & 0.1077 & 3.1028 & $2 \& 6$ \\
\hline
\end{tabular}




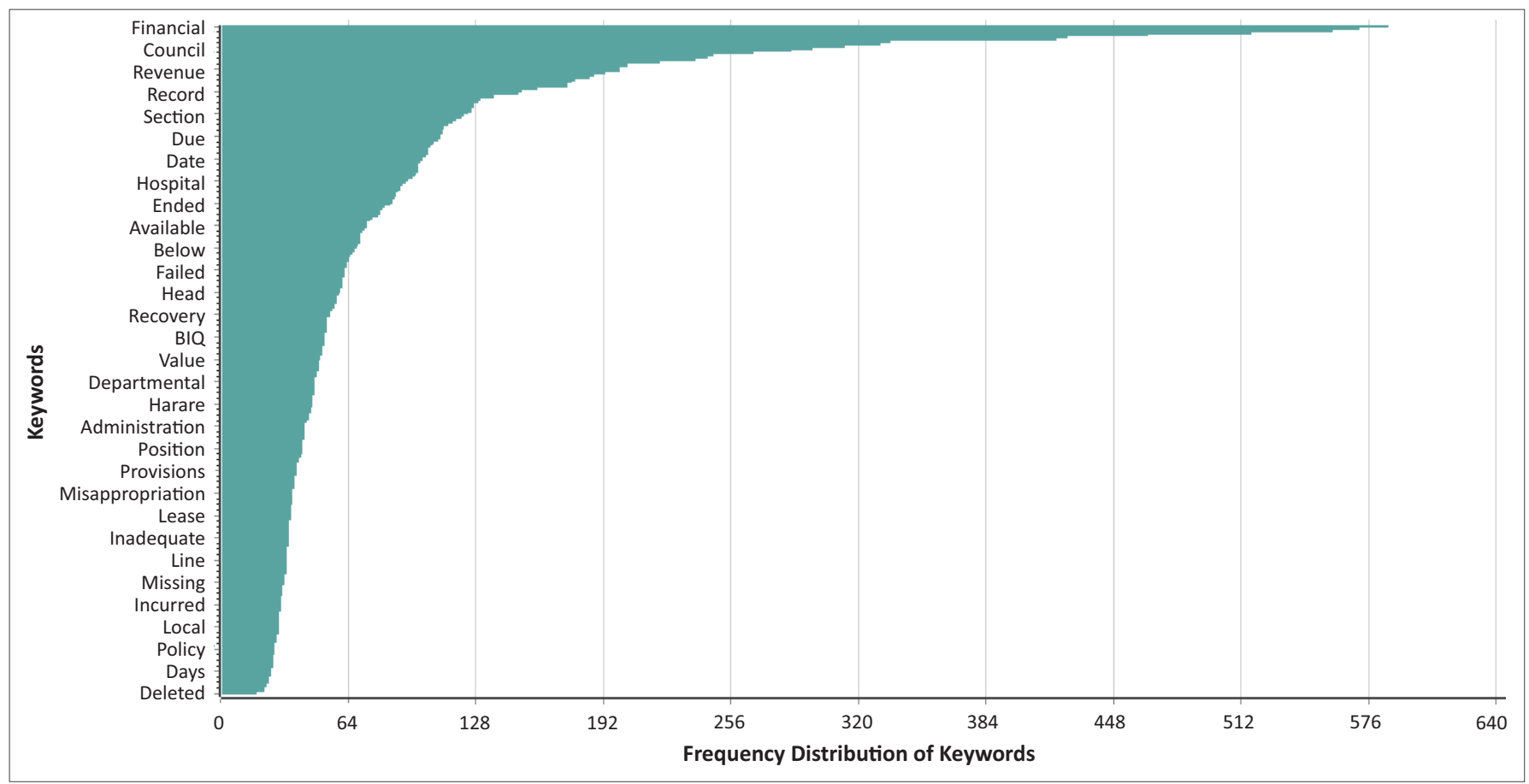

FIGURE 1: Analysis word use metrics in relation to records management issues in the narrative report.

Figures 4-9. They show that the word 'record' was heavily used in paragraph and sentence cases, which reflected concerns with regard to record-keeping. These also highlighted such issues as inadequate records, incomplete records, poor record-keeping, failure to maintain records, no improvement in record-keeping, failure to maintain up-to-date records and absence of records amongst many other challenges (see Figures 4-9). Both analyses showed a causal loop relationship between records management and auditing exercises, as well as the subsequent opinions made by the CAGZ.

Text metrics analysis using statistical methods also showed that 'record' was a heavily used word in the six reports topping amongst the top five frequently used words (Figure 1; Table 3). A further inference into this analysis through word similarity coupling and presented using a keyword Dendrogram, using a similarity index of 3 and with 10 clusters, showed that based on each of the six reports, 'record' was tightly coupled with words like recommendations, keeping, fund and evidence (Figure 3). Using a statistical prediction analysis enabled by WordStat, the results also show that most of the words tightly coupled with the word 'record' featured in all the reports six reports (Table 4). Again, inference into these statistical findings shows that records management was a strong concern in the six CAGZ narrative audit reports analysed.

\section{Implications of the results}

Government entities without records as evidence of property ownership or transactions of business with third-party institutions had no recourse in the absence of records in the event that disputes arise.

Government entities reported to have absent, incomplete or inconsistent records due to failure to maintain books of accounts, such as the cash book, relevant ledgers, expenditure vouchers, receipts and registers as well as required reconciliations, were not accountable. This was a glaring loophole for misappropriation of government or public resources as there was no evidence to charge responsible persons to be accountable for their actions. Public resources may continue to be misused with far reaching effect, particularly citizens' discontent with the effectiveness of persons running such public offices.

Lack of an integrated records management system between complementing government entities has had far reaching implications. For instance, it meant that there was no link between records of registered clients in Zimbabwe Revenue Authority's database and the companies registered with the Registrar of Companies, creating a risk that there may be more potential clients not submitting tax returns.

Government entities using paper-based, spreadsheet-based and weak payroll records processing and maintenance systems were allowing a loophole for creating ' ghost workers' as personnel profiles may easily be processed through the payroll by adding files creating or deleting electronic ones even where control systems may be in place.

Legal disputes emanating from expired lease agreements, contracts and other legally binding business transactions may be difficult to solve, resulting in a financial loss by government entities to third parties for those entities whose records were not being updated or kept sufficiently complete to serve as proof of evidence that such transactions occurred.

Absence of backups of vital records (those records without which government entities could be crippled or fail to continue) was a huge security threat and a red flag creating 


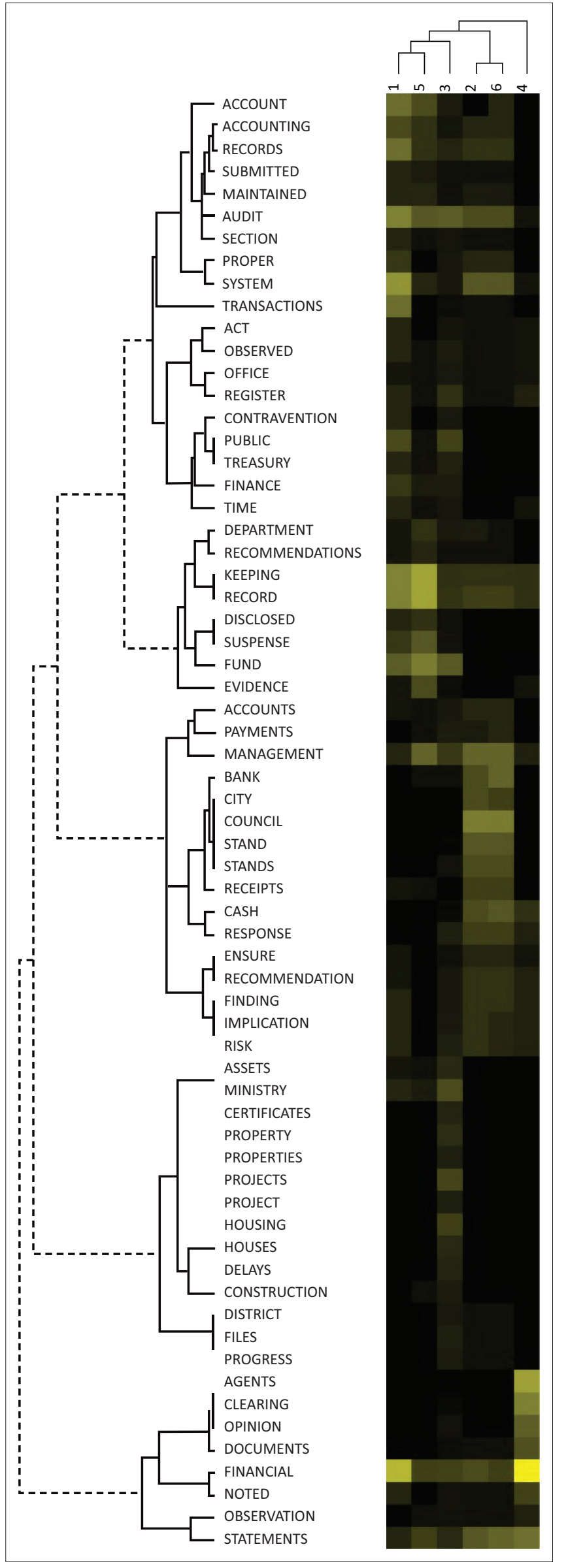

FIGURE 2: A proximity heat map showing word cluster similarities.

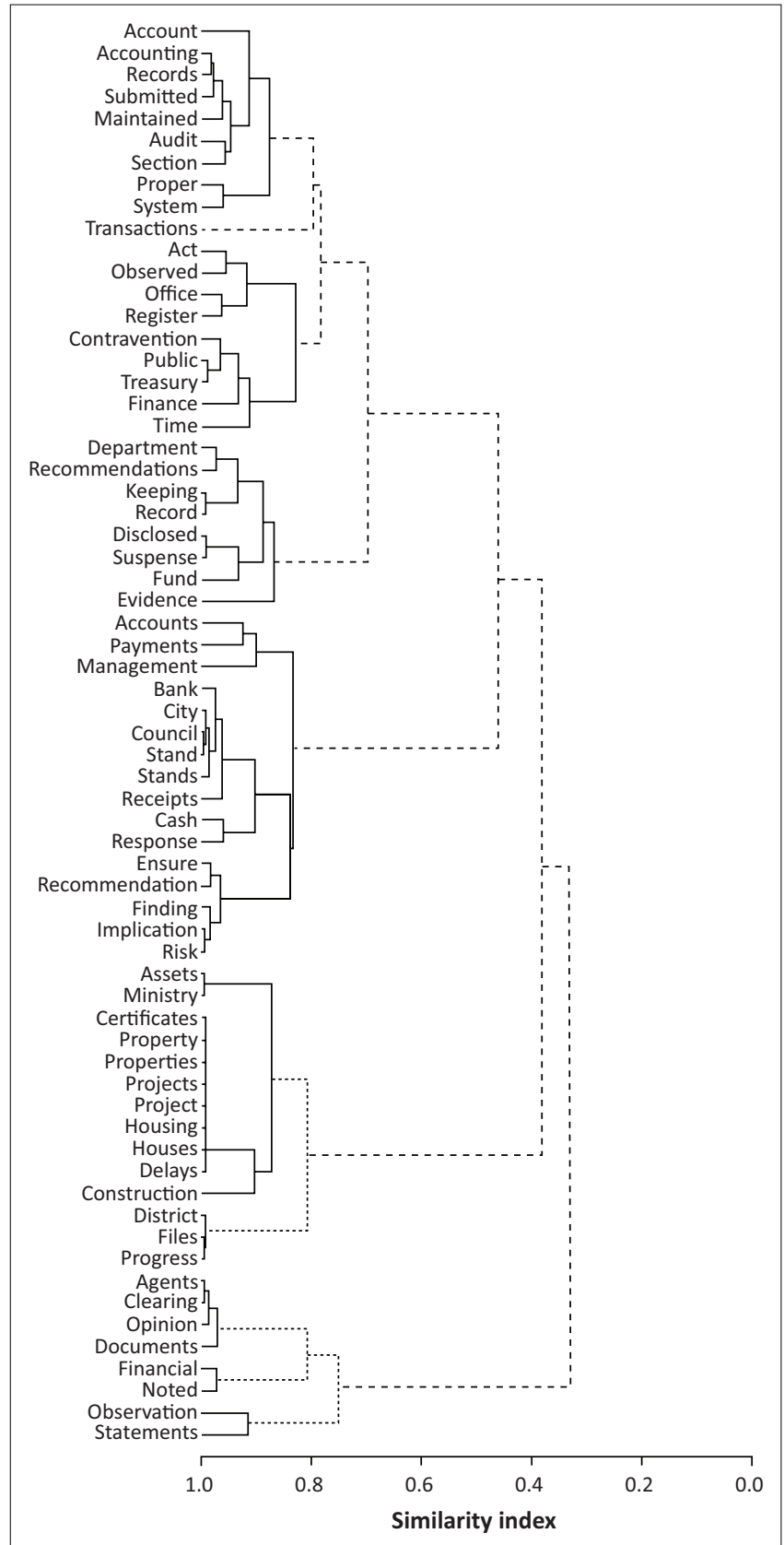

FIGURE 3: Keyword Dendrogram using a similarity index of 3 and with 10 clusters.

an ineffective risk management environment in which the institutions are vulnerable to sabotage and unforeseen disasters.

Government entities that were reported to have poor recordkeeping systems cultivated a fraudulent environment which allowed for the concealment of fraudulent activities. Errors resulting from incomplete or inaccurate records could go undetected. This further implied that financial statements presented by such government entities were not showing a true and fair view of their financial status and their financial statements could be materially misstated.

Government entities that were not keeping proper records of account for public financial management may have been in contravention of Section 298 (1) (a), (d) and (e) of the 


\begin{abstract}
N Concordance
1 the Public Finance Management Act [Chapter 22:19]. 1. GOVERNANCE ISSUES 1.1 RECORD KEEPING Finding A sample of revenue collections from entities listed in the of loans and advances and other adjustments. 1. GOVERNANCE ISSUES 1.1 RECORD KEEPING Finding I observed that Treasury did not keep proper records of The Ministry should avail documents to explain the variance of $\$ 887614423.1 .2$ RECORD KEEPING Finding I observed with concern that a guarantees register was not a database of all the registered businesses, periodic inspection of the premises and a record of land allocated to council for residential purposes should be put in place. , the vendor's financial capability, experience, reference checks, previous criminal record, tax and State Procurement Board clearance. There was no selection RECORDS Finding In my 2010 audit report, I highlighted the issue of poor record keeping that was characterised by numerous cases of mispostings, omissions records for expenditure transactions. Risk/ Implication In the absence of proper record keeping, some accounting transactions might not be recorded and processed Finance Management Act [Chapter 22:19]. Therefore, in the absence of a sound record-keeping system I could not establish the completeness and accuracy of the pleas have been made to Treasury but all these have fallen on deaf ears. The record of releases from Treasury tells the story. The Department needs urgent chairs) 51000001049351 (Video camera) 5100000113999 Risk/ Implication Failure to record assets in the Master Assets Register may result in late detection of thefts and 11 year were not disclosing SEDCO's outstanding repayments. Risk/ Implication Failure to record and prepare financial statements may result in loss of transactions information IMPLEMENTATION OF PRIOR YEAR RECOMMENDATIONS 3.1 Inventory registers to record registration plates not being maintained and closing stock not being determined was incurred for the intended purpose. There was also no register in place to record fuel received from suppliers and issued out to users for the period January to on each prospective supplier before awarding supply contracts, including its track record and capacity to deliver among other critical factors. While the Ministry any District or Provincial office results in the Head Office not having an up-to-date record. As part of the monitoring, sub national levels are regularly reminded to timely
\end{abstract}

FIGURE 4: The Comptroller and Auditor General of Zimbabwe Statements of Audited Financial Accounts for the year ended 31 December 2011 for government ministries.

Concordance

response A follow up with Zimbabwe Parks and Wildife Management Authority will be done to have a record of their movement and disposal. Campfire Manager is responsible. 2 PROCUREMENT OF GOODS The Local Board should enter into loan agreements when advancing loans to its staff and maintain a record of such agreements. Management response The observation was noted. All loans are being repaid, aggregated onto a single land bank register. This module however was not being utilised to capture and record such information of land sold and yet to be sold. Risk/ Implication Fraud or error may go record books to cater for under and over banking. Under banking invoice book Over and under banking record book or register Daily income return Cash book These records were available for your inspection. and circumstances surrounding the missing receipt books. Council should maintain a proper receipt book record which shows all receipt books issued and returned. All receipt books in Council's custody should be genuine cash payments by customers on settlement of monthly bills. The Council does not have a central record of all computers used for billing and receipting. In these circumstances, I was unable to satisfy assets. Risk/ Implication Misappropriation of assets may occur and remain undetected as no complete record of assets exists. Recommendation A comprehensive fixed assets register covering significant asset of cash deposited into the bank accounts. There was no proper accounting, regular stocktaking, complete record keeping, reconcliations or even spot audits being done for the City's security items. The City's of revenue due to Council, which may go undetected. Recommendation Council should generate duplicate record of building inspection fees, one should be given to client and the other one should be filed. These reconciled on a daily basis by the Revenue Clerk and the Accounts derks. Council maintains the following record books to cater for under and over banking. Under banking invoice book Over and under banking be easily misappropriated. Recommendation Council is advised to register the earth moving equipment for record purposes. Management response We agree with the observation, the transport superintendent is should ensure that adequate controls and suitable accounting package are in place to allow for good record keeping. Management response The organization is in the advanced stage of implementing Pastel Finding Internal control system with regards to receipting was weak. Treasury had an incomplete record of receipt books issued and this was compounded by the fact that the following four receipt books without the Town Clerk's and Council's consent. The proceeds of the sale of these stands have no record on council funds. Valuation was not done by Council and Council procedure was violated. 1.8 of ivory. However, as at December 31, 2011 the Council did not have the ivory stock at hand and no record was kept by the Council relating to either their disposal or safe keeping. Risk/ Implication was differing from the number of the actual machines that were on the ground. Therefore, there was no record of the computers that had the receipting module installed on them or were authorized to have this The tender register is also a tool that ensures that previously qualified and disqualified companies are on record and known for reference in any future tender processes. Management response The observation inspect one (1) available file out of sixty-five (65) stands administered. Risk/ Implication Lack of proper record keeping system may create opportunity for fraud. There may be double allocation of stands. Finding I was unable to carry out any detailed tests on stand sales for the year under review as the record availed for audit examination was a tattered counter book with no details relating to date of such agreements. Management response The observation was noted. All loans are being repaid, and this record is on our payroll. HWANGE LOCAL BOARD 20111 REVENUE COLLECTION AND DEBT RECOVERY 1.1

FIGURE 5: The Comptroller and Auditor General of Zimbabwe Narrative Report for the financial year ended 31 December 2012 for local authorities.

Constitution of Zimbabwe Act [No. 20] and were in contravention of Section 35 (6) (a) of the PFMA. By being unlawful they are vulnerable to the risk of constant litigation and financial loss. Such actions further cause bad reputation and citizen disapproval or public distrust in the persons running such public offices and hence the current government.

Recurrent records management concerns trending in the reports (2011-2014) appeared to show that despite its evident importance, the records management function is accorded low priority within government entities. There appeared to be a general lack of trained records management personnel in charge of records management within government entities as all the reports never gave such a report. Although reference to auditors, accountants and related financial officers was given, the reports were silent about records management officers. As such record-keeping duties seemed not to have human resource capacitation required to ensure that best practice record-keeping systems are put in place, with policies and structures required.

\section{Conclusions and recommendations}

This study proves the hypothesis that there is a strong correlation between records management concerns and audit opinions raised by the CAGZ narrative audit reports, which are a result of audit exercises in government entities. Absence, lack of or inadequate and inconsistent records management within government entities was associated with adverse and qualified opinions and, in some cases, unqualified opinions, which had emphases of matter. There was a causal loop in which lack of documentary evidence of financial activities was the source cause of poor accounting and poor audit reports with negative implications on governance. Even though important, records management still seems to be accorded low priority 


\section{Concordance}

may result in increased project costs and contractors may withdraw their services. 2.2 Record keeping The issue of record keeping was still a challenge at the Public Works Unit Vehicles is housed and maintained at Minerals Unit. The Ministry however, has a record for vehicles under the minerals unit. Most of the pool vehicles have dual number avoid being issued with duplicated receipt books in future for accountability purposes. A record of security items should always be maintained in compliance with the provisions of

of internal controls on procurement of fuel. -The Stores Department did not have a record of fuel drawn by the Departments outside the normal fuel procurement system. direct payments made by Treasury are communicated to line ministries to enable adequate record keeping at both ends. Management should consider maintaining registers for Public be understated in the financial statements. Recommendation The Fund should value and record all the assets at Khumalo Hockey Stadium in the asset register in accordance with Instructions. This was evidenced by Khumalo Hockey stadium's inability to value and record all assets under its custody leading to non-disclosure of the same in the financial and invoice books to Indo- Zimbabwe Centres in order to ensure that there is a correct record of the official receipt and invoice books in use. Management Response The record of , schools risk faling to recover the amounts completely. Recommendations An up to date record of debtors should be maintained so that schools do not loose potential revenue. The that "at the end of each term a schedule of all outstanding fees should be prepared for record purposes". This was not done because figures in the financial statements did not inadequate record keeping Risk/Implication Without registers, the Fund will not have a full record of Housing units and stands and detalls of beneficiaries of the housing scheme. are other material issues noted during the audit. 2 GOVERNANCE ISSUES 2.1 Improper Record Keeping Finding I observed with concern that Ministry officials did not maintain of Treasury Instruction 2302. This was caused by inadequate supervision and improper record keeping. The Table below refers: Stand Number Location Area Remarks 1133 4.1 Incomplete and inaccurate financial statements The Ministry made efforts to improve record keeping and preparations of financial statements during the year following workshops of Section 5.2 of the loan and performance agreements. This was caused by inadequate record keeping. Risks/Implications Outstanding loans may become irrecoverable through . 3 PROGRESS IN IMPLEMENTATION OF PRIOR YEAR RECOMMENDATIONS Inadequate Record Keeping Treasury did not keep proper records of account for Public Financial Assets beneficiaries were occupying Garikai/HalaniKuhle houses. This was caused by inadequate record keeping Risk/Implication Without registers, the Fund will not have a full record of cash must be discussed at a meeting of the Fund management and the minutes must record the resolution that was passed. The resolution must also state the specific amount to the Harare Institute of Technology Indo-Zimbabwe Centre. As a result there was no record for the following receipt books 056201-056300, 056401-056500, 725101-725200 and they were not seen when physical check of the exhibits was done in the exhibit room. No record or proof of disposal of the exhibits was availed for audit. The table 1 below refers:

for receipting at Harare Institute of Technology Indo-Zimbabwe Centre. There is no record of how these receipt books were transferred to Harare Institute of Technology.

costs and contractors may withdraw their services. 2.2 Record keeping The issue of record keeping was still a challenge at the Public Works Department as evidenced by the assessment may result in maintaining or keeping redundant and unserviceable assets on record. It may also result in procuring unsuitable or excess assets. Recommendation The internal controls. Risks/Implications It may be difficult to evict illegal occupants if an original record of the Fund's properties is not readily available. Rental income may be misstated if and submitted to the parent Ministry. Management Response The stock balance as per record need to be adjusted by 853658 litres which was released on February 1 , 2011 . on which the Fund was supposed to be generating revenue. This was caused by poor record keeping. Risk/Implication There is risk that some houses could have been converted provided to account for the difference. The anomaly could have been as a result of poor record keeping or theft of the unacquitted cash. Risk/Implication The Fund's financial return and ascertain the status of the said provincial houses. This was caused by poor record keeping and lack of supervision. Risk/Implication Houses might have been of housing properties The Ministry is still in the process of attending to the issue. 4.3 Poor record keeping of property files Property files for stand number $309,434,481$ and 666 are a shortage of architects and there were delays in payment of certificates as well as poor record keeping. 2.1 Delays in completion of construction projects The initial audit covered whose cases were on warrant of arrest. The Victoria Falls Magistrates Court should record all exhibits in the register and tag them with identifiable numbers in chronological , was involved in a "conflict of interest" whereby he was involved in a private survey, record number 152/2012 which he subsequently examined and approved for payment in his correct record of the official receipt and invoice books in use. Management Response The record of officers who collected the receipt and invoice books in question is in the stores appeals they were being caused by the accused who took time to come and inspect the record before it is sent to the High Court. I noted that Rusape Magistrates Court was not accurate information and dates as to movement of records as some sections like when the record was sent to High Court was left blank despite the records having been returned the documents. The delays in review were being caused by time being taken to type the record. On appeals they were being caused by the accused who took time to come and book number 725101-725200 was not recorded on the stores register neither is there record of who is currently using it. 1.4 Submission of Revenue Supporting Documents . The PVA screens were received well after the world cup games. The Ministry failed to record the PVA equipment in its Master Asset register. It would appear as if the Ministry

statements. Recommendation The Fund should fully utilise the accounting system to record and process all financial transactions. This will faclitate production of accurate and environment. 1.2 Audit Information System Finding The Audit Information System is used to record user activities on the SAP application system in audit logs (trails). At the time of that accounting records be maintained. The fund acquired a Promun Accounting package to record its financial information but did not fully utilise the accounting package as it was information but did not fully utlise the accounting package as it was using the system to record loan debtors only. The financial statements were prepared from the cash book and Revolving Fund Constitution. Parliament of Zimbabwe did not open books of accounts to record the indebtedness of the Members of Parliament to government. A nil return for the records with such issue vouchers. Risk/Implication Unofficial receipt books may be used to record revenue if records of issued out receipt books are not maintained resulting in the above, I noted that the Fund did not use a secure and robust accounting package to record accounting information. Ledgers were maintained on Microsoft Excel spreadsheet practice requires that an entity should use a secure and robust accounting package to record and maintain its financial information. Contrary to the above, I noted that the Fund

FIGURE 6: The Comptroller and Auditor General of Zimbabwe Narrative Report for the financial year ended 31 December 2014 for appropriation accounts and miscellaneous funds.

and importance as evidenced by recurrent concerns in the 2011-2014 reports studied.

The study recommends the strengthening of the records management legislation provided for by the National Archives of Zimbabwe Act [Chapter 25: 06] to ensure enforceability. The National Archives of Zimbabwe (NAZ) is the regulator of records management in government and the public sector and should be engaged to ensure proper management of records. Such a recommendation was never mentioned in any of the narrative reports analysed in this study and that appears to show a disjointed relationship between the CAGZ and NAZ.

Accounting, or auditing officers are given the responsibility of records management duties as stated or otherwise implied by Section 35 (6) (a) and Section 80 (2) (a) (ii) of the PFMA. These officers' training is vested in financial management and not records management. Records management should be strengthened through human resource capacitation by employing dedicated records management officers or 


\section{Concordance}

was not reconciled. The Ministry did not reconcile the variance. 2.2 Record keeping A guarantees register was not being maintained by the of completing the audit. The reconciliation had still not been done. 2.3 Record Keeping Payments to other accounts figure of $\$ 367432750$ was have been used for purposes not related to the Fund. Recommendation A record of all fuel coupons received and issued should be kept and regular

of the Statement of Public Financial Assets. Failure to keep accurate record of investments might result in the Ministry of Finance missing on August 1, 2011, however the Stadia Revolving Fund did not value and record the assets listed in the table below in the asset register in the period under review. Risk/Implication There is a risk that without any record, the assets may be lost or misappropriated. Recommendation The the Fund failing to take corrective actions. There was no improvement in record keeping. Management did not implement audit recommendations. 2.3 were being checked by the Head of Office. There was no improvement in record keeping. Management did not implement audit recommendations. 3.2 IN IMPLEMENTATION OF PRIOR YEAR RECOMMENDATIONS 2.1 Inadequate Record keeping The Ministry of Transport, Communication and

Basis for Disclaimer of Opinion 1. GOVERNANCE ISSUES 1.1. Inadequate Record Keeping and Non-disclosure of Investments Findings 1.1.1 For the no reliance could be placed on the accounts due to lack of a permanent record. Risk/Implication Unauthorized changes may be made to financial Records In my previous reports, I highlighted the issues of poor record keeping characterised by numerous mispostings, omissions and Vehicle Registry Department. 1.5 Suspense Account Finding Due to poor record keeping and weak supervisory controls, the Balance Sheet had a in the delivery of the equipment. Recommendation The Ministry should record all its advance payments in a register to facilitate follow ups. The balance. In the absence of a register for Contingent Liabilities and sound record keeping system I could not place reliance on the opening balance and commitments disclosed may be misstated, in the absence of a sound record keeping system. Recommendation The Ministry should avail had a "conflict of interest" whereby he was involved in a private survey, record number 152/2012 which he subsequently examined and approved have been made to Treasury but all these have fallen on deaf ears. The record of releases from Treasury tells the story. The Department needs spot checks and stock takes and supervise the officers responsible for the record keeping. Investigations on discrepancies are going to be conducted that an entity should use a secure and robust accounting package to record and maintain its financial information. Contrary to the above, I were received well after the world cup games. The Ministry failed to record the PVA equipment in its Master Asset register. It would appear as received and duly expended for the intended purposes. The failure to record fuel coupons bought was due to lax controls and failure by The Fund did not maintain a manual cashbook and ledgers on which to record financial transactions. This was contrary to Treasury Instruction the Fund did not use a more secure and robust accounting package to record its ledgers. Its ledgers were being maintained on Microsoft Excel did not maintain an up-to-date consolidated Master Asset Register to record all assets in terms of Treasury Instruction 2002. As a result, I could

:15] states that proper books of accounts and records should be used to record all financial transactions of the Fund. However, contrary to this stocks which is uniform so that the year-end returns reflect a true record of the stocks on hand. The Fund should on a regular basis check

FIGURE 7: The Comptroller and Auditor General of Zimbabwe Summary and Statements of Audited Financial Accounts for the year ended 31 December 2012 for government ministries.
$\mathrm{N}$ Concordance
12012 and 2013. Attendance registers play an important role of keeping a record of attendance to board and committee meetings by members. The 2 is a holder of a current certificate and also an employer shall keep a record of the particulars of the certificate relating to such workers and shall evaluate each competitive tender submitted to them during a meeting and record minutes of the evaluation process. Any tenders for the provision of of the October pay sheet the Finance Manager had to remove this dummy record from the NBA payroll. 1.2 Board meetings Finding Good corporate attached to the motor vehicle change of ownership form and retained for record keeping. Management response Observation noted. Officers have 6 . Supporting documents must be attached to the bills of entry retained for record keeping. Management response The delay in generating T1 of the 7 was added again but with a different code of NBA019FA and the old record was then deleted permanently on March $26,2013$. On 28 August 8 records should not be deleted even if they leave the organisation. The record should be frozen and its reactivation should only be made possible 9 banking details. When an employee's name is deleted in the system, all the record of payments made to such an employee are lost. I was therefore 10 encourage greater internal communication between departments in order to record transactions accurately. Progress made Bank reconciliation statements

FIGURE 8: The Comptroller and Auditor General of Zimbabwe Narrative Report for the financial year ended 31 December 2014 for state enterprises and parastatals.

otherwise retraining of accounting and auditing officers to improve records management capacitation. Employment of dedicated record-keeping officers within government entities would ensure that there are responsible personnel who could be held accountable for the records management within public entities especially for managing financial records (not the accounting or finance function). These would ensure the creation of complete records, identify activities that need to be documented as well as consistent and constant updating of the records as may be required. They would ensure that 
1 The Ministry should compile and avail for my examination a record of salary arrears and come up with plans on how the

2 fees. 1.3 Recommendation 1.3.1 The Fund should maintain a record of its payments to schools in order to monitor and use

3 . 1.3 Recommendation 1.3.1 The Ministry should receipt and record in the sub-collectors schedule all revenue received from 4 Register should be updated in order to come up with a correct record of the Ministry's assets. All new assets should be

5 Asset Register updated in order to come up with a correct record of assets. This will help the Office to establish whether 6 model or type. For the second year running the Office did not record assets that it purchased to guard against pilferage and/ which operate in Zimbabwe. No register was maintained to record all private colleges registered with the Ministry of Higher

8 4.4.1 Adequate books of accounts should be maintained to record and disclose all the financial information. EDUCATION,

FIGURE 9: The Comptroller and Auditor General of Zimbabwe Narrative Report for the financial year ended 31 December 2011 for Appropriation Accounts and Miscellaneous Funds and Donor-Funded Project.

necessary vital records identification and protection as well as disaster recovery measures are put in place to reduce security risks associated with loss of such vital documentary evidence. Such duties require qualified and trained records management officers.

The study recommends the prioritisation of the records management function within government bodies. This should be done by embedding records management operations within the financial, accounting and auditing processes of governmental bodies. Also, record-keeping systems should be mandatorily put in place with the best interest to have effective electronic systems instead of cumbersome paper-based systems, which are a huge loophole for fraud. If the above recommendations are not met, the recurrent recommendations by the CAGZ in identifying records management as one of the key sources of accountability continue to be in vain.

\section{Acknowledgements Competing interests}

The author declares that he has no financial or personal relationships that may have inappropriately influenced him in writing this article.

\section{References}

Abdolmohammadi, M.J. \& Tucker, R.R., 2002, 'The influence of accounting and auditing on a country's economic development', Review of Accounting and Finance 1(3), 42-53. https://doi.org/10.1108/eb026990

Audit and Exchequer Act (AEA) [Chapter 22: 03], 2001, Government of Zimbabwe, Government Printers, Harare.

Bhana, P., 2008, 'The contribution of proper record-keeping towards auditing and risk mitigation: Auditor General of South Africa's perspective', Paper presented at the Third Annual General Meeting of the South African Records Management Forum, Midrand, South Africa, 10-11th November, viewed from htp://sarmaf. Forum, Midrand, South Africa, 10-11th November, viewed from http://sarmaf. org.za/oid\%5Cdownloads\%5CSARMAF_10_Keynote\%20address_06
November_2008.doc

Breznau, N. 2016. 'Secondary observer effects: idiosyncratic errors in small-N secondary data analysis', International Journal of Social Research Methodology, 19(3), 301-318. https://doi.org/10.1080/13645579.2014.1001221
Chen, C.J.P., Srinidhi, B. \& Su, X., 2014, 'Effect of auditing: Evidence from variability of stock returns and trading volume', China Journal of Accounting Research 7(4) 223-245. https://doi.org/10.1016/j.cjar.2014.11.002

Constitution of Zimbabwe Act [No. 20] Act, 2013, Government of Zimbabwe, Government Printers, Harare.

DeFond, M. \& Zhang, J., 2014, 'A review of archival auditing research', Journal of Accounting and Economics 58(2), 275-326. https://doi.org/10.1016/j.jacceco. 2014.09.002

Everett, J., Neu, D. \& Rahaman, A.S., 2007, 'Accounting and the global fight against corruption', Accounting, Organizations and Society 32(6), 513-542. https://doi. org/10.1016/j.aos.2006.07.002

Kemoni, H.N., 2007, 'Records management practices and public service delivery in Kenya', PhD thesis, University of KwaZulu-Natal, Pietermaritzburg.

Lungeanu, E., 2015, 'Considerations regarding the external public audit of reimbursable funds', Procedia Economics and Finance 20, 358-364. https://doi. org/10.1016/S2212-5671(15)00084-2

Nengomasha, C.T., 2013, 'The past, present and future of records and archives management in sub-Saharan Africa', Journal of the South African Society of Archivists 46, 2-11. https://www.ajol.info/index.php/jsasa/article/view/100084/

Ngoepe, M. \& Ngulube, P., 2013, 'Contribution of record-keeping to audit opinions: An informetrics analysis of the general reports on audit outcomes of the AuditorGeneral of South Africa', Journal of the Eastern and Southern Africa Regional Branch of the International Council on Archives 32, 45-54. https://www.ajol.info/ index.php/esarjo/article/view/88541

Ngulube, P., 2004, 'Fostering accountability and justice: Opportunities for records managers in changing societies', ESARBICA Journal: Journal of the Eastern and Southern Africa Regional Branch of the International Council on Archives 23, 23-32. https://doi.org/10.1080/00039810600691288

Ngulube, P. \& Tafor, V.F., 2006, 'The management of public records and archives in the member countries of ESARBICA', Journal of the Society of Archivists 27(1), 57-83. https://doi.org/10.1080/00039810600691288

Palmer, M., 2000, 'Records management and accountability versus corruption, fraud and maladministration', Records Management Journal 10(2), 61-72. https://doi. org/10.1108/EUM0000000007256

Public Finance Management Act (PFMA) [Chapter 22: 19], 2009, Government of Zimbabwe, Government Printers, Harare.

Rezaee, Z., 2005, 'Causes, consequences, and deterrence of financial statement fraud', Critical Perspectives on Accounting 16(2005), 277-298. https://doi. org/10.1016/S1045-2354(03)00072-8

Singleton, R.A. \& Straits, B.C., 2010, Approaches to social research, 5th edn., Oxford University Press, New York.

Smith, K., 2007, Public sector records management: A practical guide, Ashgate Publishing, Ltd., Burlington, VT.

Stalebrink, O.J. \& Sacco, J.F., 2007, 'Rationalization of financial statement fraud in government: An Austrian perspective', Critical Perspectives on Accounting 18(4), 489-507. https://doi.org/10.1016/j.cpa.2006.01.009

Thurston, A., 1997, 'Records management as a public sector accountability function', International Journal of Government Auditing 24(4), 7-9. https://search.proquest. com/docview $/ 236819139$ ?accountid $=14782$

Vanasco, R.R., 1998, 'Fraud auditing', Managerial Auditing Journal 13(11), 4-71. https://doi.org/10.1108/02686909810198724 